\title{
Response of Jatropha curcas Plants to Foliar Applied Ascorbic Acid for Decreasing the Harmful Effect of Cadmium Pollution in The Irrigation Water
}

\author{
Nader A. El-Shanhorey ${ }^{1}$ and Magda A. Ahmed ${ }^{2}$ \\ ${ }^{1}$ Botanical Gardens Research Department, Horticultural Research Institute, ARC, \\ Alexandria, Egypt. \\ ${ }^{2}$ Botanical Gardens Research Department, Horticulture Research Institute, ARC, Geza, \\ Egypt.
}

\begin{abstract}
The present study was carried-out at Antoniades Research Branch, Horticultural Research Institute, A.R.C. Alexandria, Egypt during the two successive seasons of 2014 and 2015. The aim of this study was to evaluate the effects of irrigation water contaminated with cadmium on Jatropha curcas plants grown in sandy soil and the possibility of using ascorbic acid spray treatments to overcome the effects of cadmium pollution. Seedlings of Jatropha curcas were planted individually in plastic pots $(30 \mathrm{~cm}$ diameter) filled with $8 \mathrm{~kg}$ of sandy soil. The contaminated irrigation water treatments were four concentrations of cadmium $0,100,200$ and $300 \mathrm{mg} / \mathrm{l}$ were applied. The plants were also sprayed with ascorbic acid at concentrations of 0,250 and $500 \mathrm{mg} / \mathrm{l}$ by monthly spraying in both seasons.

The results showed that for vegetative growth parameters there was no significant difference in the interaction between cadmium concentrations and foliar spray by ascorbic acid. While a significant reduction was observed in all parameters after irrigation with cadmium contaminated water and a significant increase in vegetative growth parameters was observed after $500 \mathrm{mg} / \mathrm{l}$ ascorbic acid application. For chlorophyll and carbohydrate content, the highest significant value was obtained from plants irrigated with tap water and sprayed with $500 \mathrm{mg} / \mathrm{l}$ ascorbic acid while the highest significant amount of cadmium content in leaves, stem and roots was obtained from the treatment $300 \mathrm{mg} / \mathrm{l} \mathrm{cadmium}$ without application of ascorbic acid.
\end{abstract}

Key wards: Jatropha curcas, cadmium, ascorbic acid.

\section{INTRODUCTION}

Planting Jatropha in Egypt started in 2004 (SWERI, 2009). It is still in the experimental stage, but it has been proved that the potential to plant this tree is high in the marginal areas and desert. The planting of this tree has succeeded in Upper Egypt. Nevertheless, the growth and blooming periods in this area is shorter than that in other countries; it produces flowers after 18 months while in other countries it needs three years. The industrial effluents often contain large quantity of toxic heavy metals (Ghavri and Singh, 2010). These metals are non bio-degradable and persistent and can be differentially toxic to microbes (Giller et al., 2009), plants (Ghavri et al., 2010; Sharma et al., 2010), animals (Rainbow, 2007) and human being (Lim and Schoenung, 2010). Jatropha curcas L. (Family: Euphorbiaceae) is a potential biodiesel plant, which (Gunaseelan, 2009), can survive harsh environments of semi-arid agro-climatic conditions, wastelands (Mangkoedihardjo and Sunahmadia, 2008) and grows fast with little maintenance. It can reach a height of 3-8 m. Genus Jatropha has 172 species having significant economic importance is native to Central America and distributed in Africa and Asia (Cano- Asseleih et al., 1989 and Fairless, 2007). Among the various Jatropha species, J. curcas, J. glandulifera, J. gossypifolia (Achten et al., 2008), identified as the most suitable oil bearing plant, and has been recommended for plantation on waste land. Jatropha curcas L., is a perennial crop with potential such as medicinal and biodiesel 
crop recently and is recognized as potential oil seed (Effendi et al., 2010; Rafii et al., 2012; Shabanimofrad et al., 2011). This plant has a great importance as a medicinal plant in treating tropical diseases of dermatological origin (Igbinosa et al., 2009). Also the attention on this crop has increased due to high rate of ozone layer depletion and global warming effect caused by increased usage of fossil fuel resulting in environmental pollution. Renewable biofuel feed stocks are perceived to be essential contributors to the energy supply portfolio as they contribute to the world energy supply security, reducing dependency on fossil fuel resources and provide opportunity for mitigating greenhouse gases (Sudhakar and Nalini, 2011). This newly introduced crop, which grows abundantly in wild and abandoned land, has its seed and oil yield unpredictable especially in tropical climate. Favourable environmental conditions that affect its production are yet to be known (Ovando-Medina et al., 2011 and Divakara et al., 2010). Ginwal et al. (2005) reported that Jatropha has adapted itself to wide range of environmental and ecological conditions which suggests that, there exists considerable amount of genetic diversity yet to be detected for potential realization (Rao et al., 2008).

Plants need trace amount of heavy metal but their excessive availability may cause plant toxicity (Sharma et al., 2006). Phytotoxic concentration of the heavy metals referred in the literature does not always specify the levels (Wua et al., 2010). Cadmium is a toxic heavy metal that has an environmental concern (Mahler et al., 1981). There are many sources of environmental cadmium pollution, including fuel combustion, industrial sludges, phosphate fertilizers, and mine tailings (Unhalekhana and Kositanont, 2008). Cadmium can be absorbed by the human body through respiration and consumption, and cadmium then accumulates in the liver and kidney, causing acute and chronic symptoms such as nausea, abdominal pain, diarrhea, kidney dysfunction, and osteomalacia (Simmons et al., 2005).

Ascorbic acid is an essential antioxidant in the ascorbate-glutathione pathway, but it also protects enzymes that have prosthetic transition metal ions. Furthermore, it is a cofactor for many enzymes, including those involved in the cell wall synthesis, most notably in the hydroxylation of proline residues (Ishikawa et al. 2006). Moreover, alternative oxidase can be induced by $\mathrm{H}_{2} \mathrm{O}_{2}$ accumulation and, as ascorbate is involved in controlling the intracellular $\mathrm{H}_{2} \mathrm{O}_{2}$ level, this might provide the means for a concerted interaction to protect the cell against uncontrolled oxidation (Bartoli et al. 2006).

In this study Jatropha curcas was selected due to its characteristics as non-edible plant which can grow in tropical areas and its commercial viability for the production of biodiesel, therefore the objective of this study is to determine the potential of Jatropha curcas in removing heavy metals from the soil affected contaminated irrigation water and to investigate on the ability of Jatropha in removing heavy metals. 


\section{MATERIALS AND METHODS}

The present study was carried-out at Antoniades Research Branch, Horticultural Research Institute, A.R.C. Alexandria, Egypt during the two successive seasons of 2014 and 2015 . The aim of this study was to evaluate the effects of irrigation water contaminated with cadmium on Jatropha curcas plants grown in sandy soil, the possibility of using ascorbic acid spray treatments to overcome the effects of cadmium pollution.

On the $15^{\text {th }}$ of February, 2014 and 2015 (in the first and second seasons, respectively) identical seedlings of Jatropha curcas $(70-80 \mathrm{~cm}$ height and $20-25$ leaves per plant in average) were planted individually in plastic pots $(30 \mathrm{~cm}$ diameter) filled with $8 \mathrm{~kg}$ of sandy soil. The chemical constituents of the soil were measured as described by Jackson (1958) in Table (1).

Table (1). Chemical analyses of the used sandy soil for the two successive seasons 2014 and 2015.

\begin{tabular}{lccccccccc}
\hline \multirow{2}{*}{ Season } & \multirow{2}{*}{$\mathrm{pH}$} & $\mathrm{EC}$ & \multicolumn{4}{c}{ Soluble cations (meq/l) } & \multicolumn{3}{c}{ Soluble anions (meq/I) } \\
\cline { 4 - 10 } & & $\left(\mathbf{d S m}^{-1}\right)$ & $\mathbf{C a}^{++}$ & $\mathbf{M g}^{++}$ & $\mathbf{N a}^{+}$ & $\mathbf{K}^{+}$ & $\mathbf{H C O}_{3}^{-}$ & $\mathbf{C l}^{-}$ & $\mathbf{S O}_{2}^{--}$ \\
\hline $\mathbf{2 0 1 4}$ & 7.94 & 1.57 & 3.4 & 3.4 & 6.5 & 1.2 & 3.6 & 6.7 & 2.4 \\
$\mathbf{2 0 1 5}$ & 7.91 & 1.52 & 3.2 & 3.0 & 6.3 & 1.1 & 3.3 & 6.5 & 2.2 \\
\hline
\end{tabular}

On the $1^{\text {st }}$ of March (in both seasons), the contaminated irrigation water treatments were initiated. Four concentrations of cadmium acetate $\left[\left(\mathrm{CH}_{3} \mathrm{COO}\right)_{2}\right.$ $\left.\mathrm{Cd} .2 \mathrm{H}_{2} \mathrm{O}\right]$ 0,100, 200 and $300 \mathrm{mg} / \mathrm{l}$ were applied. The plants were irrigated three times per week; at the end of the experiment every plant received about 250 liters per pot of contaminated water in Table (2). In both seasons, the plants were received by monthly spraying from $15^{\text {th }}$ May till $15^{\text {th }}$ August in both seasons. The plants were also sprayed with ascorbic acid at concentrations of 0,250 and $500 \mathrm{mg} / \mathrm{l}$. Control plants were sprayed with tap water. On $30^{\text {th }}$ of September in the both seasons, the plants were harvested.

Table (2). Total amount of the water used for each plant (I/pot) in each treatment during the growing two season of 2014 and 2015.

\begin{tabular}{|c|c|c|c|c|c|c|c|c|}
\hline \multirow{2}{*}{$\begin{array}{c}\text { Field } \\
\text { Capacity (\%) }\end{array}$} & \multicolumn{7}{|c|}{ Months of first and second seasons } \\
\cline { 2 - 9 } & March & April & May & June & July & August & September & Total \\
\hline $\mathbf{9 0 \%}$ & 28.00 & 30.00 & 32.00 & 35.00 & 40.00 & 45.00 & 40.00 & $\mathbf{2 5 0 . 0 0}$ \\
\hline
\end{tabular}

In the two seasons, all plants received NPK chemical fertilization using soluble fertilizer (Kristalon 19-19-19) at the rate of $3 \mathrm{~g} /$ pot. Fertilization was repeated every 30 days throughout the growing season (from the $1^{\text {th }}$ of March till the $30^{\text {th }}$ of September). In addition, weeds were removed manually upon emergence. 


\section{Data recorded :}

(1) Vegetative growth parameters:

Plant height $(\mathrm{cm})$, number of leaves per plant, leaves dry weight per plant $(\mathrm{g})$, leaves area $\left(\mathrm{cm}^{2}\right)$ according to Koller (1972), stem diameter (cm), stem dry weight $(\mathrm{g})$, root length $(\mathrm{cm})$ and root dry weight $(\mathrm{g})$.

\section{(2) Chemical analysis determination:}

- Total chlorophylls content was determined as a SPAD from the fresh leaves of plants for the different treatments under the experiment at the end of the season using Minolta (chlorophyll meter) SPAD 502 according to Yadava (1986).

- Total carbohydrates percentage in the leaves was determined according to Dubios et al.(1956).

- Determination of Cadmium content. Plant samples were divided into leaves stem and roots. They were then dried at $72^{\circ} \mathrm{C}$ in an oven until completely dried. The dried plant samples were ground to powder. The dried samples were then digested for extraction of cadmium, using the method described by Piper (1947) method and the concentration of heavy metal was determined using an atomic absorption spectrophotometer.

- Available heavy metal, i.e. (Cadmium) in soil samples were extracted by DPTA solution according to Lindsay and Norvell (1978) and determined by Inductively Coupled Plasma Spectrometry.

- Transfer factor (TF) is given by the relation: the ratio of the concentration of metal in the shoots to the concentration of metal in the soil (Chen et al., 2004). The transfer factor is a value used in evaluation studies on the impact of routine or accidental releases of pollutant into the environment.

The layout of the experimental design was split plot design with three replicates. Each replicate contained three plants. The main plots were the contaminated irrigation water levels while the sup plots were the concentrations of ascorbic acid. The means of the individual factors and their interactions were compared by L.S.D test at $5 \%$ level of probability according to Snedecor and Cochran (1974).

\section{RESULTS}

\section{Vegetative growth: Plant height $(\mathrm{cm})$}

Data presented in Table (3) Showed that, in both seasons, irrigation water contaminated with cadmium decreased the height of Jatropha curcas plants, compared to plants irrigated with tap water (control). Plants irrigated with tap water had the highest mean values of plant height 43.49 and $47.33 \mathrm{~cm}$ in the first and second seasons, respectively. Moreover, raising the cadmium concentration caused steady significant reductions in plant height, with the highest concentration (300 mg/l) giving significantly the shortest plants (with mean heights of 33.36 and $36.49 \mathrm{~cm}$ in the two seasons, respectively) than those receiving any other cadmium concentration. 
Plant height was also significantly affected by spraying the plants with ascorbic acid. In both seasons, plant height increased gradually when the ascorbic acid concentration was raised from $0 \mathrm{mg} / \mathrm{l}$ (control) to $500 \mathrm{mg} / \mathrm{l}$. Accordingly, it can be seen from the data in Table (3) that Jatropha curcas plants sprayed with $500 \mathrm{mg} / \mathrm{l}$ ascorbic acid were significantly taller (with mean plant heights of 39.70 and $42.60 \mathrm{~cm}$ in the first and second seasons, respectively) than plants sprayed with any other ascorbic acid concentrations.

Regarding the interaction between the effects of irrigation with contaminated cadmium water and ascorbic acid treatments on growth rate of the plant height of Jatropha curcas plants, the results recorded in the two seasons show that, the highest values were obtained in the plants irrigated with tap water and sprayed with ascorbic acid at $500 \mathrm{mg} / \mathrm{l}$ (with mean heights of 44.91 and $48.50 \mathrm{~cm}$ in the first and second seasons, respectively). On the other hand, the shortest plants (with mean heights of 30.25 and $33.83 \mathrm{~cm}$ in the first and second seasons, respectively) were resulted in when the plants were irrigated using the highest cadmium concentration $(300 \mathrm{mg} / \mathrm{l})$ without ascorbic acid treatment. It can also been seen from the data presented in Table (3) that in many cases, spraying the plants with ascorbic acid reduced the undesirable effect of contaminated water with cadmium.

\section{Number of leaves per plant}

The data presented in Table (3) show the effect of contaminated water with cadmium on number of leaves formed on Jatropha curcas plants. In both seasons, plants irrigated with tap water had the highest number of leaves 21.71 and 19.99 leaves per plant in the first and second seasons, respectively. While, the lowest number of leaves (16.83 and 15.27 leaves per plant in the first and second seasons, respectively), was formed by plants that were irrigated using the highest cadmium concentration (300 mg/l).

Concerning the effect of ascorbic acid treatments on the number of leaves, the data recorded in the two seasons (Table 3 ) show that only one ascorbic acid treatment $500 \mathrm{mg} / \mathrm{l}$ caused a significant increase in the number of leaves giving mean values of 19.95 and 17.91 leaves per plant in the first and second seasons, respectively, compared to that of control plants (17.62 and 16.62 leaves per plant in the two seasons, respectively).

Data in Table (3) show that, significant interaction was detected in both seasons between the effects of irrigation with contaminated cadmium water and ascorbic acid treatments on the number of leaves formed by Jatropha curcas plants. Combining irrigation using tap water with spraying the plants with ascorbic acid at $500 \mathrm{mg} / \mathrm{l}$ gave the highest number of leaves of 22.33 and 20.50 leaves per plant in the first and second seasons, respectively. On the other hand, the lowest number of leaves of 15.33 and 14.33 leaves per plant in the first and second seasons, respectively, were obtained on plants irrigated using the highest cadmium concentration $300 \mathrm{mg} / \mathrm{l}$ and sprayed without any ascorbic acid concentration. 


\section{Leaves dry weight $(g)$ per plant}

The results recorded in the two seasons Table (3) show that the highest dry weight values of leaves (20.22 and $22.00 \mathrm{~g}$ in the first and second seasons, respectively), were obtained from plants irrigated with tap water. Moreover, the recorded values were decreased steadily with raising the cadmium concentration. Accordingly, the lowest values 15.50 and $16.96 \mathrm{~g}$ per plant in the first and second seasons, respectively, were obtained from plants irrigated with the highest cadmium concentration $300 \mathrm{mg} / \mathrm{l}$.

Data presented In Table (3) also show that spraying Jatropha curcas plants with ascorbic acid at $500 \mathrm{mg} / \mathrm{l}$ significantly increased the dry weight of leaves giving values of 18.46 and $19.80 \mathrm{~g}$ per plant in the first and second seasons, respectively, compared to the control (16.28 and $18.33 \mathrm{~g}$ per plant in the first and second seasons, respectively).

Regarding the interaction between the effects of irrigation with contaminated cadmium water and ascorbic acid treatments on the dry weight of leaves of Jatropha curcas, the data presented in Table (3) showed that the highest dry weight values of leaves of $(20.88$ and $22.55 \mathrm{~g}$ in the first and second seasons, respectively), were obtained in plants irrigated with tap water and sprayed with ascorbic acid at $500 \mathrm{mg} / \mathrm{l}$, whereas the lowest dry weights of leaves of 14.06 and $15.73 \mathrm{~g}$ in the first and second seasons, respectively, were obtained when the plants were irrigated using the highest cadmium concentration $300 \mathrm{mg} / \mathrm{l}$ without any ascorbic acid treatment.

\section{Leaves area $\left(\mathrm{cm}^{2}\right)$}

The results recorded for both seasons Table (3) show that irrigation with contaminated cadmium water decreased the leaf area of Jatropha curcas plants, compared to plants irrigated with tap water (control). In both seasons, plants irrigated with tap water (control) had the largest leaves with mean areas of 1172.80 and $1284.13 \mathrm{~cm}^{2}$ in the first and second seasons, respectively. The leaf area was decreased steadily with raising the cadmium concentration. Accordingly, the smallest leaves with mean areas of 699.96 and $763.92 \mathrm{~cm}^{2}$ in the first and second seasons, respectively, were those formed on plants that were irrigated using the highest cadmium concentration $300 \mathrm{mg} / \mathrm{l}$.

Data presented in Table (3) show that, in most cases, the different ascorbic acid treatments had no significant effect on leaf area of Jatropha curcas plants. The only exception to this common trend was recorded in the first season, with plants sprayed using ascorbic acid at $500 \mathrm{mg} / \mathrm{l}$ forming significantly larger leaves with a mean area of $\left(1021.99\right.$ and $1095.17 \mathrm{~cm}^{2}$ in the first and second seasons, respectively), than those formed by control plants (731.25 and $825.93 \mathrm{~cm}^{2}$ ).

Data presented in Table (3) also show that significant interaction was detected between the effects of irrigation with contaminated cadmium water and ascorbic acid treatments on the area of Jatropha curcas leaves. The largest leaves with mean areas of 1375.95 and $1499.90 \mathrm{~cm} 2$ in the first and second 
seasons, respectively, was formed by plants irrigated with tap water and sprayed with ascorbic acid at $500 \mathrm{mg} / \mathrm{l}$. On the other hand, the smallest leaves (with areas of 584.20 and $654.73 \mathrm{~cm}^{2}$ in the first and second seasons, respectively) were obtained on plants irrigated using the highest cadmium concentration $300 \mathrm{mg} / \mathrm{l}$ at the lowest concentration $0 \mathrm{mg} / \mathrm{l}$ ascorbic acid treatment.

Table (3). Averages of plant height (cm), number of leaves per plant, leaves dry weight $(\mathrm{g})$ and leaves area $\left(\mathrm{cm}^{2}\right)$ of Jatropha curcas plants as influenced by Cadmium (Cd), Ascorbic acid (AA) and their combinations ( $\mathrm{Cd} \times \mathrm{AA}$ ) in the two seasons of 2014 and 2015.

\begin{tabular}{|c|c|c|c|c|c|c|c|c|c|}
\hline \multicolumn{2}{|c|}{ Treatments } & \multicolumn{2}{|c|}{$\begin{array}{l}\text { Plant height } \\
\text { (cm) }\end{array}$} & \multicolumn{2}{|c|}{$\begin{array}{c}\text { Number of } \\
\text { leaves per } \\
\text { plant }\end{array}$} & \multicolumn{2}{|c|}{$\begin{array}{l}\text { Leaves dry } \\
\text { weight } \\
\text { (g) }\end{array}$} & \multicolumn{2}{|c|}{ Leaves area $\left(\mathrm{cm}^{2}\right)$} \\
\hline $\begin{array}{c}\text { Cd } \\
(\mathrm{mg} / \mathrm{l})\end{array}$ & $\begin{array}{l}\text { Ascorbic } \\
\text { acid } \\
\text { (mg/l) }\end{array}$ & 2014 & 2015 & 2014 & 2015 & 2014 & 2015 & 2014 & 2015 \\
\hline \multirow{3}{*}{0} & 0 & .33 & 46.50 & 21.16 & 19.66 & 19.68 & 21.62 & 941.91 & 1040.20 \\
\hline & 250 & 43.25 & 47.00 & 21.66 & 19.83 & 20.10 & 21.85 & 1200.54 & 1312.31 \\
\hline & 500 & 44.91 & 48.50 & 22.33 & 20.50 & 20.88 & 22.55 & 1375.95 & 1499.90 \\
\hline \multicolumn{2}{|c|}{ Average } & 43.49 & 47.33 & 21.71 & 19.99 & 20.22 & 22.00 & 1172.80 & 1284.13 \\
\hline \multirow{3}{*}{100} & 0 & 33.66 & 40.50 & 16.83 & 17.00 & 15.65 & 18.83 & 710.53 & 859.89 \\
\hline & 250 & 37.16 & 42.08 & 18.83 & 17.50 & 17.28 & 19.56 & 860.86 & 961.16 \\
\hline & 500 & 39.83 & 43.83 & 20.16 & 18.33 & 18.52 & 20.37 & 994.41 & 1077.91 \\
\hline \multicolumn{2}{|c|}{ Average } & 36.88 & 42.13 & 18.60 & 17.61 & 17.15 & 19.58 & 855.26 & 966.32 \\
\hline \multirow{3}{*}{200} & 0 & 33.91 & 36.91 & 17.16 & 15.50 & 15.76 & 17.16 & 688.38 & 748.90 \\
\hline & 250 & 36.33 & 39.75 & 18.33 & 16.83 & 16.89 & 18.48 & 803.18 & 884.10 \\
\hline & 500 & 38.25 & 40.08 & 19.33 & 17.00 & 17.78 & 18.63 & 893.20 & 932.70 \\
\hline \multicolumn{2}{|c|}{ Average } & 36.16 & 38.91 & 18.27 & 16.44 & 16.81 & 18.09 & 794.92 & 855.23 \\
\hline \multirow{3}{*}{300} & 0 & & & 15.33 & 14.33 & 14.06 & 15.73 & & 654.73 \\
\hline & 250 & 34.00 & 37.66 & 17.16 & 15.66 & 15.80 & 17 & & 766.84 \\
\hline & 500 & 35.83 & 38.00 & 18.00 & 15.83 & 16.66 & 17.66 & 824.40 & 870.20 \\
\hline \multicolumn{2}{|c|}{ Averaqe } & 33.36 & 36.49 & 16.83 & 15.27 & 15.50 & 16.96 & 699.96 & 763.92 \\
\hline \multirow{3}{*}{$\begin{array}{c}\text { Mean } \\
(\mathrm{AA})\end{array}$} & 0 & 35.03 & 39.43 & 17.62 & 16.62 & 16.28 & 18.33 & 731.25 & 825.93 \\
\hline & 250 & 37.68 & 41.62 & 18.99 & 17.45 & 17.51 & 19.35 & 888.97 & 981.10 \\
\hline & 500 & 39.70 & 42.60 & 19.95 & 17.91 & 18.46 & 19.80 & 1021.99 & 1095.17 \\
\hline \multirow{3}{*}{$\begin{array}{l}\text { L.S.D. } \\
\text { at } \\
0.05\end{array}$} & Cd & 1.77 & 1.36 & 0.95 & 1.60 & 0.82 & 0.63 & 44.10 & 36.23 \\
\hline & $\mathbf{A A}$ & 0.81 & 0.86 & 0.41 & 0.45 & 0.37 & 0.40 & 18.25 & 22.40 \\
\hline & $\mathrm{Cd}^{*} \mathrm{AA}$ & 1.86 & 1.98 & 0.95 & 1.03 & 0.86 & 0.92 & 42.02 & 51.57 \\
\hline
\end{tabular}

\section{Stem diameter $(\mathbf{c m})$}

The data recorded for the stem diameter of Jatropha curcas plants in the two seasons Table (4) show that irrigation with contaminated cadmium water decreased stem thickness, compared to that of plants irrigated with tap water (control). In both seasons, plants irrigated with tap water had the thickest stems, with mean diameters of 5.28 and $5.75 \mathrm{~cm}$ in the first and second seasons, respectively. Raising the cadmium concentration in irrigation water caused a 
steady reduction in stem diameter. This reduction in stem diameter was significant (compared to the control), even at the lowest cadmium concentration (300 mg/l), which gave stem diameters of 4.05 and $4.43 \mathrm{~cm}$ in the first and second seasons, respectively.

In contrast to the effect of cadmium treatments, ascorbic acid treatments improved stem diameter of Jatropha curcas plants, compared to the control. Moreover, plants sprayed with $500 \mathrm{mg} / \mathrm{l}$ ascorbic acid had significantly thickest stems (with mean diameters of 4.82 and $5.18 \mathrm{~cm}$ in the first and second seasons, respectively), compared to the those of control plants, or plants sprayed with any other ascorbic acid concentration.

Regarding the interaction between the effects of irrigation with contaminated cadmium water and ascorbic acid treatments on growth rate of the stem diameter of Jatropha curcas plants, the results recorded for the two seasons (Table 4) show that significant differences were detected between the values obtained from plants receiving the different treatment combinations. The highest values $(5.46$ and $5.90 \mathrm{~cm}$ in the first and second seasons, respectively) were obtained in the plants irrigated with tap water and sprayed with ascorbic acid at $500 \mathrm{mg} / \mathrm{l}$. On the other hand, the thinnest stems (with diameters of 3.68 and $4.11 \mathrm{~cm}$ in the first and second seasons, respectively) were obtained in the plants irrigated using the highest cadmium concentration $300 \mathrm{mg} / \mathrm{l}$ without ascorbic acid treatment. It can also be seen that in some cases, the ascorbic acid treatments helped to overcome the adverse effect of the cadmium treatments on stem thickening.

\section{Stem dry weight $(\mathbf{g})$}

Data presented in Table (4) show that, in both seasons, irrigation using contaminated water with cadmium significantly decreased dry weights of stem of Jatropha curcas plants, compared to plants irrigated with tap water (control). Plants irrigated with tap water had the heaviest mean dry weight of stems 37.25 and $41.34 \mathrm{~g}$ per plant in the first and second seasons, respectively. The dry weight of stems showed a gradual reduction as the cadmium concentration was increased. Accordingly, the lowest dry weights of stem 30.16 and $33.57 \mathrm{~g}$ per plant in the first and second seasons, respectively, were recorded in plants receiving the highest cadmium concentration $300 \mathrm{mg} / \mathrm{l}$.

The results recorded in the two seasons (Table 4) show that, in both seasons, spraying the plants with ascorbic acid increased the dry weight of stem. In both seasons, spraying plants with $500 \mathrm{mg} / \mathrm{l}$ ascorbic acid gave the heaviest dry weight of stem 34.09 and $37.47 \mathrm{~g}$ per plant in the first and second seasons, respectively. These values were significantly higher than those of control plants, or plants receiving any other ascorbic acid concentration.

Regarding the interaction between the effects of irrigation contaminated water with cadmium and ascorbic acid treatments, the results recorded in the two seasons show that the heaviest stems dry weights of 38.55 and $42.01 \mathrm{~g}$ per plant in the first and second seasons, respectively, were those of plants irrigated with tap water and sprayed without ascorbic acid. On the other hand, 
the lowest stem dry weights (29.28 and $32.52 \mathrm{~g}$ per plant in the first and second seasons, respectively) were obtained in plants irrigated using the highest cadmium concentrations $300 \mathrm{mg} / \mathrm{l}$ without ascorbic acid treatment.

\section{Root length (cm)}

Data presented in Table (4) show that all the tested treatments of irrigation water contaminated with cadmium significantly decreased the root length $(\mathrm{cm})$ of Jatropha curcas, compared to that of plants irrigated with tap water (control). In both seasons, plants irrigated with tap water had the highest mean root length 50.02 and $49.60 \mathrm{~cm}$ in the first and second seasons, respectively. Raising the cadmium concentration caused a steady reduction in the root length, which reached its lowest values 38.35 and $40.37 \mathrm{~cm}$ in the first and second seasons, respectively, in plants irrigated using the highest cadmium concentration $300 \mathrm{mg} / \mathrm{l}$.

The data in Table (4) also indicate that ascorbic acid treatments had a significant effect on the root length. In both seasons, Jatropha curcas plants sprayed with ascorbic acid, compared to the control plants. As with the other vegetative growth parameters, spraying the plants with ascorbic acid at 500 $\mathrm{mg} / \mathrm{l}$ gave the heaviest root length 45.65 and $45.87 \mathrm{~cm}$ in the first and second seasons, respectively.

Regarding the interaction between the effects of irrigation using water contaminated with cadmium and ascorbic acid treatments on root length of Jatropha curcas plants, the results recorded in the two seasons showed that, the highest values were obtained in plants irrigated with tap water and sprayed with ascorbic acid at $500 \mathrm{mg} / \mathrm{l}$ (with mean length of 51.65 and $50.69 \mathrm{~cm}$ in the first and second seasons, respectively). On the other hand, the shortest roots (with mean length of 31.78 and $39.57 \mathrm{~cm}$ in the first and second seasons, respectively) were those irrigated using the highest cadmium concentration 300 $\mathrm{mg} / \mathrm{l}$ without ascorbic acid treatment. It can also been seen from the data presented in Table (4) that in many cases, spraying the plants with ascorbic acid reduced the undesirable effect of cadmium.

\section{Root dry weight (g)}

Data presented in Table (4) show that irrigation of Jatropha curcas plants using water contaminated with cadmium significantly decreased the dry weights of roots, compared to plants irrigated with tap water (control). In both seasons, plants irrigated with tap water had the heaviest dry weight of roots 28.73 and $31.67 \mathrm{~g}$ per plant in the first and second seasons, respectively. Steady significant reductions in the dry weight of roots were recorded as the cadmium concentration in the irrigation water was increased, with the highest cadmium concentration $300 \mathrm{mg} / \mathrm{l}$ giving the lowest mean values in both seasons 22.83 and $25.26 \mathrm{~g}$ per plant in the first and second seasons, respectively.

Regarding the effect of ascorbic acid treatments on the dry weight of roots, data in Table (4) show that spraying Jatropha curcas plants with ascorbic 
acid at $500 \mathrm{mg} / \mathrm{l}$ significantly increased the recorded values, compared to the control. The highest weight dry roots 25.59 and $28.13 \mathrm{~g}$ per plant in the first and second seasons, respectively, were those of plants sprayed with ascorbic acid at $500 \mathrm{mg} / \mathrm{l}$.

Regarding the interaction between the effects of irrigation using water contaminated with cadmium and ascorbic acid treatments, the data presented in Table (4) show that the highest values (29.71 and $32.28 \mathrm{~g}$ per plant in the first and second seasons, respectively) were obtained in plants irrigated with tap water and sprayed without ascorbic acid. On the other hand, the lowest dry weight of roots (21.67 and $24.12 \mathrm{~g}$ per plant in the first and second seasons, respectively) were obtained from plants irrigated using the highest cadmium concentration $300 \mathrm{mg} / \mathrm{l}$, with no ascorbic acid treatment.

Table (4). Averages of stem diameter (cm), stem dry weight (g), root length (cm) and root dry weight (g) of Jatropha curcas plants as influenced by Cadmium (Cd), Ascorbic acid (AA) and their combinations (Cd $\times$ AA) in the two seasons of 2014 and 2015.

\begin{tabular}{|c|c|c|c|c|c|c|c|c|c|}
\hline \multicolumn{2}{|c|}{ reatments } & \multicolumn{2}{|c|}{$\begin{array}{c}\text { Stem } \\
\text { diameter }(\mathrm{cm})\end{array}$} & \multicolumn{2}{|c|}{$\begin{array}{c}\text { Stem dry } \\
\text { weight }(g)\end{array}$} & \multicolumn{2}{|c|}{$\begin{array}{l}\text { Root length } \\
(\mathrm{cm})\end{array}$} & \multicolumn{2}{|c|}{$\begin{array}{c}\text { Root dry } \\
\text { weight (g) }\end{array}$} \\
\hline $\begin{array}{c}\text { Cd } \\
(\mathrm{mg} / \mathrm{l})\end{array}$ & $\begin{array}{l}\text { Ascorbic } \\
\text { acid(mg/l) }\end{array}$ & 2014 & 2015 & 2014 & 2015 & 2014 & 2015 & 2014 & 2015 \\
\hline \multirow{3}{*}{000} & 0 & 5.14 & 5.65 & 38.55 & 42.01 & 48.68 & 48.77 & 29.71 & 32.28 \\
\hline & 250 & 5.26 & 5.72 & 36.35 & 41.08 & 49.73 & 49.35 & 28.23 & 31.46 \\
\hline & 500 & 5.46 & 5.90 & 36.85 & 40.93 & 51.65 & 50.69 & 28.26 & 31.27 \\
\hline \multicolumn{2}{|c|}{ Average } & 5.28 & 5.75 & 37.25 & 41.34 & 50.02 & 49.60 & 28.73 & 31.67 \\
\hline \multirow{3}{*}{100} & 0 & 4.09 & 4.92 & 29.32 & 32.20 & 38.71 & 38.81 & 23.29 & 25.88 \\
\hline & 250 & 4.52 & 5.12 & 32.10 & 34.66 & 42.73 & 42.73 & 24.57 & 27.52 \\
\hline & 500 & 4.84 & 5.33 & 33.50 & 37.27 & 45.80 & 44.94 & 25.31 & 28.05 \\
\hline \multicolumn{2}{|c|}{ Average } & 4.48 & 5.12 & 31.64 & 34.71 & 42.41 & 42.16 & 24.39 & 27.15 \\
\hline \multirow{3}{*}{200} & 0 & 4.12 & 4.49 & 26.00 & 29.30 & 39.05 & 35.36 & 21.89 & 23.96 \\
\hline & 250 & 4.42 & 4.83 & 33.50 & 35.97 & 41.77 & 42.26 & 25.19 & 27.21 \\
\hline & 500 & 4.65 & 4.87 & 34.77 & 37.25 & 43.98 & 46.09 & 25.26 & 27.23 \\
\hline \multicolumn{2}{|c|}{ Average } & 4.39 & 4.73 & 31.42 & 34.17 & 41.60 & 41.23 & 24.11 & 26.13 \\
\hline \multirow{3}{*}{300} & 0 & 3.68 & 4.11 & 29.28 & 32.52 & 34.78 & 39.57 & 21.67 & 24.12 \\
\hline & 250 & 4.13 & 4.58 & 29.93 & 33.75 & 39.09 & 39.76 & 23.29 & 25.70 \\
\hline & 500 & 4.36 & 4.62 & 31.27 & 34.45 & 41.20 & 41.78 & 23.54 & 25.98 \\
\hline \multicolumn{2}{|c|}{ Average } & 4.05 & 4.43 & 30.16 & 33.57 & 38.35 & 40.37 & 22.83 & 25.26 \\
\hline \multirow{3}{*}{$\begin{array}{l}\text { Mean } \\
(\mathrm{AA})\end{array}$} & 0 & 4.25 & 4.79 & 30.78 & 34.00 & 40.30 & 40.62 & 24.14 & 26.56 \\
\hline & 250 & 4.58 & 5.06 & 32.97 & 36.36 & 43.33 & 43.52 & 25.32 & 27.97 \\
\hline & 500 & 4.82 & 5.18 & 34.09 & 37.47 & 45.65 & 45.87 & 25.59 & 28.13 \\
\hline \multirow{3}{*}{$\begin{array}{l}\text { L.S.D. } \\
\text { at } 0.05\end{array}$} & Cd & 0.21 & 0.16 & 1.45 & 1.61 & 2.05 & 1.56 & 1.10 & 1.08 \\
\hline & $\overline{A A}$ & 0.09 & 0.10 & 0.55 & 0.58 & 0.94 & 0.74 & 0.21 & 0.34 \\
\hline & $\mathrm{Cd}^{*} \mathrm{AA}$ & 0.21 & 0.23 & 1.28 & 1.34 & 2.17 & 1.72 & 0.50 & 0.78 \\
\hline
\end{tabular}




\section{Chemical constituents Total chlorophyll content (SPAD)}

The results presented in Table (5) show that the highest content of total chlorophyll was obtained in plant irrigation with tap water 54.52 and 54.73 SPAD in the first and second seasons, respectively. Raising the cadmium concentration in irrigation water resulted in steady significant reductions in the total chlorophyll content, which reached its lowest value 49.46 and 49.89 SPAD in the first and second seasons, respectively, in plants receiving the highest cadmium concentration $300 \mathrm{mg} / \mathrm{l}$.

The results of leaf chemical analysis Table (5) also show that ascorbic acid treatments had clear effect on the total chlorophyll content. The recorded mean values ranged from 53.79 and 53.96 SPAD in the first and second seasons, respectively, in plants sprayed with ascorbic acid at $250 \mathrm{mg} / \mathrm{l}$ to 48.92 and 49.43 SPAD in the first and second seasons, respectively, in plants sprayed with ascorbic acid at $0 \mathrm{mg} / \mathrm{l}$.

Regarding to the interaction between the effects of irrigation using water contaminated with cadmium and ascorbic acid treatments, the data presented in Table (5) showed that the highest total chlorophyll contents of 56.19 and 56.29 in the first and second seasons, respectively, were found in leaves of plants irrigated with tap water and sprayed with ascorbic acid at $500 \mathrm{mg} / \mathrm{l}$, the lowest values of 46.37 and 47.13 in the first and second seasons, respectively, were obtained in plants irrigated with cadmium water at $100 \mathrm{mg} / \mathrm{l}$ and sprayed with tap water.

\section{Carbohydrates content (\%)}

Data resulting from chemical analysis Table (5) show that, the total carbohydrates \% in the dried leaves of Jatropha curcas plants was decreased steadily with raising the cadmium concentration in the irrigation contaminated water with cadmium. The highest mean carbohydrates content 20.28 and 20.27 $\%$ in the first and second seasons, respectively, was found in the leaves of control plants, whereas the lowest mean value 18.15 and $18.48 \%$ in the first and second seasons, respectively, was found in plants irrigated with water containing the highest cadmium concentration $300 \mathrm{mg} / \mathrm{l}$.

The results in Table (5) also show that most of the tested ascorbic acid concentrations increased the mean total carbohydrates \% in the leaves of Jatropha curcas plants, compared to the control. Among the plants receiving the different ascorbic acid treatments, plants sprayed with $250 \mathrm{mg} / \mathrm{l}$ ascorbic acid had the highest carbohydrate \% in leaves 19.55 and $19.83 \%$ in the first and second seasons, respectively.

Concerning the interaction between the effects of irrigation using water contaminated with cadmium and ascorbic acid treatments on the carbohydrates content \% of leaves. The results presented in Table (5) show that the highest mean values of 20.82 and $20.85 \%$ in the first and second seasons, 
respectively, were obtained in the leaves of plants irrigated with tap water and sprayed with ascorbic acid at $500 \mathrm{mg} / \mathrm{l}$. On the other hand, the lowest carbohydrates content was obtained in the leaves of plants irrigated with cadmium water at $100 \mathrm{mg} / \mathrm{l}$ and receiving no ascorbic acid treatment.

\section{Cadmium content in leaves $(\mathrm{mg} / \mathrm{kg})$}

The data resulting from leaves chemical analysis Table (5) show that, the cadmium content $(\mathrm{mg} / \mathrm{kg}$ ) in the dried leaves of Jatropha curcas plants was raised steadily with raising the cadmium concentration in the irrigation water. The lowest mean cadmium content 0.002 and $0.003 \mathrm{mg} / \mathrm{kg}$ in the first and second seasons, respectively, was found in the leaves of control plants, whereas the highest mean value 0.009 and $0.010 \mathrm{mg} / \mathrm{kg}$ in the first and second seasons, respectively, was found in plants irrigated with water containing the highest cadmium concentration $300 \mathrm{mg} / \mathrm{l}$.

Concerning the effect of ascorbic acid treatments on the cadmium content in leaves, the data recorded in the two seasons Table (5) show that only one ascorbic acid treatment $500 \mathrm{mg} / \mathrm{l}$ caused a significant decrease in the cadmium content in leaves giving mean values of 0.003 and $0.004 \mathrm{mg} / \mathrm{kg}$ in the first and second seasons, respectively, compared to that of control plants had the highest cadmium content in leaves 0.008 and $0.009 \mathrm{mg} / \mathrm{kg}$ in the first and second seasons, respectively.

Concerning the interaction between the effects of irrigation using water contaminated with cadmium and ascorbic acid treatments on the cadmium content in leaves. The results in Table (5) show that the lowest mean values of 0.002 and $0.002 \mathrm{mg} / \mathrm{kg}$ in the first and second seasons, respectively, were obtained in the leaves of plants irrigated with tap water and sprayed with ascorbic acid at $500 \mathrm{mg} / \mathrm{l}$. On the other hand, the highest cadmium content was obtained in the leaves of irrigated with cadmium water at $300 \mathrm{mg} / \mathrm{l}$ and receiving no ascorbic acid treatment $(0.014$ and $0.015 \mathrm{mg} / \mathrm{kg}$ in the first and second seasons, respectively).

\section{Cadmium content in stem $(\mathrm{mg} / \mathrm{kg})$}

The data resulting from stem chemical analysis Table (5) show that, the cadmium content $(\mathrm{mg} / \mathrm{kg})$ in the dried stem of Jatropha curcas plants was raised steadily with raising the cadmium concentration in the irrigation water. The lowest mean cadmium content 0.007 and $0.009 \mathrm{mg} / \mathrm{kg}$ in the first and second seasons, respectively, was found in the stem of control plants, whereas the highest mean value 0.023 and $0.029 \mathrm{mg} / \mathrm{kg}$ in the first and second seasons, respectively, was found in plants irrigated with water containing the highest cadmium concentration $300 \mathrm{mg} / \mathrm{l}$.

Concerning the effect of ascorbic acid treatments on the cadmium content in stem, the data recorded in the two seasons Table (5) show that only one ascorbic acid treatment $500 \mathrm{mg} / \mathrm{l}$ caused a significant decrease in the cadmium content in stem giving mean values of 0.011 and $0.012 \mathrm{mg} / \mathrm{kg}$ in the first and second seasons, respectively, compared to that of control plants had 
the highest cadmium content in stem 0.026 and $0.028 \mathrm{mg} / \mathrm{kg}$ in the first and second seasons, respectively.

Concerning the interaction between the effects of irrigation using water contaminated with cadmium and ascorbic acid treatments on the cadmium content in stem. The results in Table (5) show that the lowest mean values of 0.005 and $0.006 \mathrm{mg} / \mathrm{kg}$ in the first and second seasons, respectively, were obtained in the stem of plants irrigated with tap water and sprayed with ascorbic acid at $500 \mathrm{mg} / \mathrm{l}$. On the other hand, the highest cadmium content was obtained in the stem of irrigated with cadmium water at $300 \mathrm{mg} / \mathrm{l}$ and receiving no ascorbic acid treatment $(0.041$ and $0.045 \mathrm{mg} / \mathrm{kg}$ in the first and second seasons, respectively).

\section{Cadmium content in roots $(\mathrm{mg} / \mathrm{kg})$}

The data resulting from roots chemical analysis Table (5) show that, the cadmium content $(\mathrm{mg} / \mathrm{kg})$ in the dried roots of Jatropha curcas plants was raised steadily with raising the cadmium concentration in the irrigation water. The lowest mean cadmium content 0.011 and $0.013 \mathrm{mg} / \mathrm{kg}$ in the first and second seasons, respectively, was found in the roots of control plants, whereas the highest mean value 0.039 and $0.042 \mathrm{mg} / \mathrm{kg}$ in the first and second seasons, respectively, was found in plants irrigated with water containing the highest cadmium concentration $300 \mathrm{mg} / \mathrm{l}$.

Concerning the effect of ascorbic acid treatments on the cadmium content in roots, the data recorded in the two seasons Table (5) show that only one ascorbic acid treatment $500 \mathrm{mg} / \mathrm{l}$ caused a significant decrease in the cadmium content in roots giving mean values of 0.016 and $0.018 \mathrm{mg} / \mathrm{kg}$ in the first and second seasons, respectively, compared to that of control plants had the highest cadmium content in roots 0.038 and $0.041 \mathrm{mg} / \mathrm{kg}$ in the first and second seasons, respectively.

Concerning the interaction between the effects of irrigation using water contaminated with cadmium and ascorbic acid treatments on the cadmium content in roots. The results in Table (5) show that the lowest mean values of 0.008 and $0.009 \mathrm{mg} / \mathrm{kg}$ in the first and second seasons, respectively, were obtained in the roots of plants irrigated with tap water and sprayed with ascorbic acid at $500 \mathrm{mg} / \mathrm{l}$. On the other hand, the highest cadmium content was obtained in the roots of irrigated with cadmium water at $300 \mathrm{mg} / \mathrm{l}$ and receiving no ascorbic acid treatment $(0.059$ and $0.065 \mathrm{mg} / \mathrm{kg}$ in the first and second seasons, respectively). 
Table (5). Averages of chemical constituents characteristics of Jatropha curcas plants as influenced by cadmium (Cd), Ascorbic acid (AA) and their combinations $(\mathrm{Cd} \times \mathrm{AA})$ in the two seasons of 2014 and 2015.

\begin{tabular}{|c|c|c|c|c|c|c|c|c|c|c|c|}
\hline \multicolumn{2}{|c|}{ Treatments } & \multicolumn{2}{|c|}{$\begin{array}{c}\text { Chlorophyll } \\
\text { content (SPAD) }\end{array}$} & \multicolumn{2}{|c|}{$\begin{array}{c}\text { Carbohydrates } \\
\text { content (\%) }\end{array}$} & \multicolumn{2}{|c|}{$\begin{array}{l}\text { Cadmium content } \\
\text { in leaves }(\mathrm{mg} / \mathrm{kg})\end{array}$} & \multicolumn{2}{|c|}{$\begin{array}{c}\text { Cadmium content } \\
\text { in stem }(\mathrm{mg} / \mathrm{kg})\end{array}$} & \multicolumn{2}{|c|}{$\begin{array}{l}\text { Cadmium content } \\
\text { in roots }(\mathrm{mg} / \mathrm{kg})\end{array}$} \\
\hline $\begin{array}{c}\text { Cd } \\
(\mathrm{mg} / \mathrm{l})\end{array}$ & $\begin{array}{c}\text { Ascorbic acid } \\
(\mathrm{mg} / \mathrm{l})\end{array}$ & 2014 & 2015 & 2014 & 2015 & 2014 & 2015 & 2014 & 2015 & 2014 & 2015 \\
\hline \multirow{3}{*}{000} & 0 & 52.87 & 53.29 & 19.84 & 19.75 & 0.003 & 0.004 & 0.010 & 0.012 & 0.014 & 0.017 \\
\hline & 250 & 54.52 & 54.61 & 20.20 & 20.23 & 0.003 & 0.003 & 0.008 & 0.009 & 0.012 & 0.013 \\
\hline & 500 & 56.19 & 56.29 & 20.82 & 20.85 & 0.002 & 0.002 & 0.005 & 0.006 & 0.008 & 0.009 \\
\hline \multicolumn{2}{|c|}{ Average } & 54.52 & 54.73 & 20.28 & 20.27 & 0.002 & 0.003 & 0.007 & 0.009 & 0.011 & 0.013 \\
\hline \multirow{3}{*}{100} & 0 & 46.37 & 47.13 & 17.18 & 17.46 & 0.007 & 0.007 & 0.022 & 0.022 & 0.032 & 0.032 \\
\hline & 250 & 55.77 & 55.86 & 20.18 & 20.43 & 0.007 & 0.006 & 0.020 & 0.020 & 0.029 & 0.028 \\
\hline & 500 & 54.00 & 54.42 & 19.73 & 20.14 & 0.003 & 0.004 & 0.010 & 0.012 & 0.015 & 0.017 \\
\hline \multicolumn{2}{|c|}{ Average } & 52.04 & 52.47 & 19.03 & 19.34 & 0.005 & 0.005 & 0.017 & 0.018 & 0.025 & 0.025 \\
\hline \multirow{3}{*}{200} & 0 & 49.04 & 49.13 & 17.90 & 18.20 & 0.011 & 0.012 & 0.033 & 0.035 & 0.048 & 0.050 \\
\hline & 250 & 53.36 & 53.45 & 19.26 & 19.45 & 0.008 & 0.008 & 0.024 & 0.025 & 0.035 & 0.036 \\
\hline & 500 & 52.44 & 52.53 & 18.67 & 18.78 & 0.005 & 0.006 & 0.016 & 0.018 & 0.023 & 0.026 \\
\hline \multicolumn{2}{|c|}{ Average } & 51.61 & 51.70 & 18.61 & 18.81 & 0.008 & 0.008 & 0.024 & 0.026 & 0.035 & 0.037 \\
\hline \multirow{3}{*}{300} & 0 & 47.42 & 48.17 & 17.56 & 17.84 & 0.014 & 0.015 & 0.041 & 0.045 & 0.059 & 0.065 \\
\hline & 250 & 51.51 & 51.95 & 18.57 & 19.24 & 0.009 & 0.010 & 0.027 & 0.029 & 0.038 & 0.041 \\
\hline & 500 & 49.47 & 49.57 & 18.33 & 18.36 & 0.005 & 0.005 & 0.014 & 0.015 & 0.020 & 0.021 \\
\hline \multicolumn{2}{|c|}{ Average } & 49.46 & 49.89 & 18.15 & 18.48 & 0.009 & 0.010 & 0.027 & 0.029 & 0.039 & 0.042 \\
\hline \multirow{3}{*}{ Mean $(A A)$} & 0 & 48.92 & 49.43 & 18.12 & 18.31 & 0.008 & 0.009 & 0.026 & 0.028 & 0.038 & 0.041 \\
\hline & 250 & 53.79 & 53.96 & 19.55 & 19.83 & 0.006 & 0.006 & 0.019 & 0.020 & 0.028 & 0.029 \\
\hline & 500 & 53.02 & 53.20 & 19.38 & 19.53 & 0.003 & 0.004 & 0.011 & 0.012 & 0.016 & 0.018 \\
\hline \multirow{3}{*}{$\begin{array}{l}\text { L.S.D. at } \\
0.05\end{array}$} & Cd & 0.71 & 0.82 & 0.79 & 0.28 & 0.003 & 0.004 & 0.009 & 0.013 & 0.012 & 0.019 \\
\hline & AA & 0.84 & 0.81 & 0.43 & 0.35 & 0.002 & 0.003 & 0.005 & 0.008 & 0.007 & 0.012 \\
\hline & $\mathrm{Cd}^{*} \mathrm{AA}$ & 1.94 & 1.86 & 0.98 & 0.82 & 0.004 & 0.006 & 0.012 & 0.020 & 0.015 & 0.027 \\
\hline
\end{tabular}




\section{Transfer factor (TF) of heavy metals}

Transfer factor (TF) indicates the efficiency of plants to transfer metals from root to the aerial parts.

\section{Cadmium content in soil samples $(\mathrm{mg} / \mathrm{kg})$}

Data in Table (6) showed that the lowest average of cadmium content was observed in soil cultured by untreated plants, while the highest average of cadmium content was observed in soil after the treatment $300 \mathrm{mg} / \mathrm{l}$ cadmium and $0 \mathrm{mg} / \mathrm{l}$ ascorbic acid.

Table (6). Average of cadmium content in soil samples as influenced by cadmium concentrations in irrigation water and foliar application of citric acid on Jatropha curcas leaves at the end of second season (2015).

\begin{tabular}{ccc}
\hline \multicolumn{2}{c}{ Treatments } & Cadmium content in soil $(\mathbf{m g} / \mathbf{k g})$ \\
\cline { 1 - 2 } $\mathbf{C d}(\mathbf{m g} / \mathbf{l})$ & Ascorbic acid $(\mathbf{m g} / \mathbf{l})$ & \\
\hline \multirow{2}{*}{$\mathbf{0}$} & 0 & 0.018 \\
& 250 & 0.014 \\
\multirow{3}{*}{$\mathbf{1 0 0}$} & 500 & 0.011 \\
& 0 & 0.024 \\
& 250 & 0.022 \\
\multirow{2}{*}{$\mathbf{2 0 0}$} & 500 & 0.021 \\
& 0 & 0.050 \\
\multirow{2}{*}{$\mathbf{3 0 0}$} & 250 & 0.048 \\
& 500 & 0.046 \\
\hline
\end{tabular}

\section{Transfer factor to leaves (TFL)}

From the data presented in Table (7), it can be seen that the transfer factor in the dried leaves of Jatropha curcas plants was decreased steadily with raising the cadmium concentration in the irrigation water. Accordingly, the lowest cadmium value ( 0.143 in the second season) was found in plants irrigated with water containing cadmium concentration $300 \mathrm{mg} / \mathrm{l}$, whereas the highest value ( 0.251 in the second season) was found in plants irrigated with water containing cadmium concentration $100 \mathrm{mg} / \mathrm{l}$.

The results in Table (7) also show that the transfer factor in the dried leaves was reduced steadily with raising ascorbic acid concentration. Accordingly, the highest cadmium value ( 0.240 in the second season) was recorded in the leaves of control plants, whereas plants sprayed with the highest ascorbic acid concentration $500 \mathrm{mg} / \mathrm{l}$ had the lowest cadmium value (0.144 in the second season). 
Regarding the interaction between effect of irrigation using water contaminated with cadmium and ascorbic acid concentrations on the transfer factor in the dried leaves, the data in Table (7) show that the highest mean values 0.291 in the second season, was obtained in plants irrigated with cadmium water at $100 \mathrm{mg} / \mathrm{l}$ and sprayed with tap water, while the lowest mean values 0.320 in the second season, was recorded in plants irrigated with cadmium water at $300 \mathrm{mg} / \mathrm{l}$ and sprayed with ascorbic acid at $500 \mathrm{mg} / \mathrm{l}$.

\section{Transfer factor to stem (TFS)}

From the data presented in Table (7), it can be seen that the transfer factor in the dried stem of Jatropha curcas plants was decreased steadily with raising the cadmium concentration in the irrigation water. Accordingly, the lowest cadmium value (0.726 in the second season) was found in plants irrigated with water containing cadmium concentration $300 \mathrm{mg} / \mathrm{l}$, whereas the highest value ( 0.798 in the second season) was found in plants irrigated with water containing cadmium concentration $100 \mathrm{mg} / \mathrm{l}$.

The results in Table (7) also show that the transfer factor in the dried stem was reduced steadily with raising ascorbic acid concentration. Accordingly, the highest cadmium value (0.726 in the second season) was recorded in the stem of control plants, whereas plants sprayed with the highest ascorbic acid concentration $500 \mathrm{mg} / \mathrm{l}$ had the lowest cadmium value (0.434 in the second season).

Regarding the interaction between effect of irrigation using water contaminated with cadmium and ascorbic acid concentrations on the transfer factor in the dried stem, the data in Table (7) show that the highest mean values 0.916 in the first and second season, was obtained in plants irrigated with cadmium water at $100 \mathrm{mg} / \mathrm{l}$ and sprayed with tap water, while the lowest mean values 0.230 in the second season, was recorded in plants irrigated with cadmium water at $300 \mathrm{mg} / \mathrm{l}$ and sprayed with ascorbic acid at $500 \mathrm{mg} / \mathrm{l}$.

\section{Transfer factor to roots (TFR)}

From the data presented in Table (7), it can be seen that the transfer factor in the dried roots of Jatropha curcas plants was decreased steadily with raising the cadmium concentration in the irrigation water. Accordingly, the lowest cadmium value (0.609 in the second season) was found in plants irrigated with water containing cadmium concentration $300 \mathrm{mg} / \mathrm{l}$, whereas the highest value (1.137 in the second season) was found in plants irrigated with water containing cadmium concentration $100 \mathrm{mg} / \mathrm{l}$.

The results in Table (7) also show that the transfer factor in the dried roots was reduced steadily with raising ascorbic acid concentration. Accordingly, the highest cadmium value (1.044 in the second season) was recorded in the roots of control plants, whereas plants sprayed with the highest ascorbic acid concentration $500 \mathrm{mg} / \mathrm{l}$ had the lowest cadmium value $(0.628 \mathrm{in}$ the second season). 
Regarding the interaction between effect of irrigation using water contaminated with cadmium and ascorbic acid concentrations on the transfer factor in the dried roots, the data in Table (7) show that the highest mean values 1.333 in the first and second season, was obtained in plants irrigated with cadmium water at $100 \mathrm{mg} / \mathrm{l}$ and sprayed with tap water, while the lowest mean values 0.323 in the second season, was recorded in plants irrigated with cadmium water at $300 \mathrm{mg} / \mathrm{l}$ and sprayed with ascorbic acid at $500 \mathrm{mg} / \mathrm{l}$.

Table (7). Averages of transfer factor to leaves, stem and roots of Jatropha curcas plants as influenced by cadmium (Cd), ascorbic acid (AA) and their combinations $(\mathrm{Cd} \times \mathrm{AA})$ in the two seasons of 2014 and 2015.

\begin{tabular}{|c|c|c|c|c|}
\hline \multicolumn{2}{|c|}{ Treatments } & \multirow{2}{*}{$\begin{array}{c}\begin{array}{c}\text { Transfer } \\
\text { factor to leaves } \\
\text { (TFL) }\end{array} \\
2015\end{array}$} & \multirow{2}{*}{$\begin{array}{c}\begin{array}{c}\text { Transfer } \\
\text { factor to stem } \\
\text { (TFS) }\end{array} \\
2015\end{array}$} & \multirow{2}{*}{$\begin{array}{c}\begin{array}{c}\text { Transfer } \\
\text { factor to roots } \\
\text { (TFR) }\end{array} \\
2015\end{array}$} \\
\hline $\mathrm{Cd}(\mathrm{mg} / \mathrm{l})$ & $\begin{array}{c}\text { Ascorbic } \\
\text { acid }(\mathrm{mg} / \mathrm{l})\end{array}$ & & & \\
\hline \multirow{3}{*}{000} & 0 & 0.222 & 0.666 & 0.944 \\
\hline & 250 & 0.214 & 0.642 & 0.928 \\
\hline & 500 & 0.181 & 0.545 & 0.818 \\
\hline \multicolumn{2}{|c|}{ Average } & 0.205 & 0.617 & 0.896 \\
\hline \multirow{3}{*}{100} & 0 & 0.291 & 0.916 & 1.333 \\
\hline & 250 & 0.272 & 0.909 & 1.271 \\
\hline & 500 & 0.190 & 0.571 & 0.809 \\
\hline \multicolumn{2}{|c|}{ Average } & 0.251 & 0.798 & 1.137 \\
\hline \multirow{3}{*}{200} & 0 & 0.240 & 0.700 & 1.000 \\
\hline & 250 & 0.166 & 0.520 & 0.750 \\
\hline & 500 & 0.130 & 0.391 & 0.565 \\
\hline \multicolumn{2}{|c|}{ Average } & 0.178 & 0.537 & 0.771 \\
\hline \multirow{3}{*}{300} & 0 & 0.208 & 0.625 & 0.902 \\
\hline & 250 & 0.147 & 0.426 & 0.602 \\
\hline & 500 & 0.076 & 0.230 & 0.323 \\
\hline \multicolumn{2}{|c|}{ Average } & 0.143 & 0.427 & 0.609 \\
\hline \multirow{3}{*}{ Mean (AA) } & 0 & 0.240 & 0.726 & 1.044 \\
\hline & 250 & 0.199 & 0.624 & 0.887 \\
\hline & 500 & 0.144 & 0.434 & 0.628 \\
\hline \multirow{3}{*}{$\begin{array}{l}\text { L.S.D. at } \\
0.05\end{array}$} & Cd & 0.029 & 0.085 & 0.121 \\
\hline & AA & 0.022 & 0.066 & 0.095 \\
\hline & $C d^{*} A A$ & 0.051 & 0.152 & 0.218 \\
\hline
\end{tabular}

\section{DISCUSSION}

This study revealed that at high heavy-metal concentrations, the plant height was significantly reduced, and the biomass was decreased. The root growth was more sensitive than other parameters, as roots rapidly absorbed water and had higher accumulations of heavy metal elements. The results presented by this study were in agreement with earlier reports on other plants, such as aquatic plant wolffia arrhiza (Piotrowska et al., 2010), barley Hordeum vulgare (Tiryakioglu et al., 2006) and typha angustifolia (Bah et al., 2011). Other 
studies with woody plant reported a higher inhibition of root elongation (Dominguez et al., 2009). In particular, Jatropha plants could bioaccumulate and bioconcentrate toxic heavy metals from an aqueous solution (Mohammad et al., 2010) and could be used as phytoremediation candidates in some countries (Juwarkar et al., 2008; Kumar et al., 2008; Jamil et al., 2009). Additionally, the plant seedling exhibited a high root/shoot ratio throughout the experiment. An alternative explanation might relate to a strong root system with many roots spread out over the entire soil for survival because root/shoot ratio could reflect plant's response to various environment factors (Otieno et al., 2005; Lukacova Kulikova and Lux, 2010; Li et al., 2010).

The physiological responses, such as the gas exchange rate and photosynthetic function, can be ascribed to the different effects of physicochemical properties of heavy metals on the integrity and function of the photochemical apparatus of plant seedling fronds, as well as the impact on the chlorophyll concentrations in the leaves. The photosynthesis rate, CO2 assimilation rate, and stomatal conductance in response to cadmium heavy metal have been well documented (Chen et al., 2012). The maintenance of an intercellular $\mathrm{CO} 2$ concentration is concomitant with the leaf $\mathrm{CO} 2$ assimilation rate and reflected photosynthesis function of seedling in the different heavy metal-spiked soils. The chlorophyll and carotenoid contents played a central role in the energy manifestation of green plant. Any significant alteration of their contents possibly resulted in a marked effect on the entire metabolism of the plant (Piotrowska et al., 2010). In this study, cadmium resulted in a significant reduction in the chlorophyll contents, possibly due to the inhibition of chlorophyll biosynthesis or a breakdown of pigments and their precursors (Agrawal and Mishra, 2009). cadmium might replace the central $\mathrm{Mg}$ from chlorophyll molecules and thereby reduce the photosynthetic light-harvesting ability of plant (Agrawal and Mishra, 2009). In contrast, Car were less sensitive than Chl a and $\mathrm{Chl} b$ in response to both cadmium heavy metals, which probably facilitated the maintenance of photosynthetic apparatus against heavy metal stress (Piotrowska et al., 2010). Car stabilized and protected the lipid phase of the thylakoid membrane by serving as the antioxidant to scavenge the free radicals (Polle et al., 1992; Piotrowska et al., 2010).

Concerning treatments and the control sample, at a preliminary stage, one should note that the transfer factor of most treatments is lower than one for cadmium; which means that the physiological need of the plant for these elements is rather limited.

Trace elements translocation from roots to shoots via a number of physiological processes, including metal unloading into root xylem cells, longdistance carrying from the xylem to the shoots and metal reabsorption, by leaf mesophyll cells, from the xylem stream. Once the trace metals have been unloaded into the xylem vessels, the metals are carried to the shoots by the transpiration stream (Blaylock and Huang, 2000).

Ascorbic acid is the widely known compound used as an antioxidant and the most effective compound increasing the tolerance of plants to oxidative 
stresses. Confirmed the role of ascorbic acid in oxidative stress or scavenging freeoxy-radicals (Smith et al., 1989). In addition, ascorbic acid affects the physiological activities of the plants. Also, there is evidence that the tolerance of plants is correlated with the increased amount of ascorbic acid. The antioxidant defense system in the plant cells includes both enzymatic antioxidants such as Superoxide Dismutase, Catalase, Ascorbate Peroxidase and non-enzymatic antioxidants like ascorbic acid, Glutathione and tocopherol. When plants are subjected to environmental stresses, oxidative damage may result because the balance between the production of Reactive Oxygen Substances and their detoxification by the antioxidative system is altered (Gomez et al., 1999). Tolerance to damaging environmental stresses is correlated with an increased capacity to scavenge or detoxify Reactive Oxygen Substances (Foyer et al., 1994). Taking all these observations together, it may be suggested as a hypothetical framework that $\mathrm{Cd}$ induces a transient loss in antioxidative capacity perhaps accompanied by a stimulation of oxidant producing enzymes, which results in intrinsic ascorbic acid accumulation. ascorbic acid then would act as a signalling molecule triggering secondary defences.

\section{CONCLUSIONS}

The concentrations of heavy metals increase in the environment from year to year. Therefore decontamination of heavy metal-contaminated water and soils is very important for maintenance of environmental health and ecological restoration. Phytoremediation is a new cleanup concept that involves the use of plants to clean or stabilize contaminated environments. Phytoremediation of metals is the most effective plant-based method to remove pollutants from contaminated areas. This green technology can be applied to remediate the polluted soils without creating any destructive effect of soil structure. Some specific plants, such as woody species, have been proven to have noticeable potential to absorb toxic heavy metals.

Phytoremediation of contaminated water and soil with heavy metals using non-edible plant like Jatropha curcas offers an environmental friendly and cost-effective method for remediating the polluted soil. The Jatropha curcas was found to be able to efficiently remove the heavy metals such as cadmium.

\section{REFERENCES}

Achten W.M.J., Verchot L., Franken Y.J., Mathij E., Singh V.P., Aerts R. and Muys B. (2008). Jat ropha bio-diesel product ion and use. Biomass Bioenergy, 32: 1063-1084.

Agrawal S.B. and Mishra S. (2009). Effects of supplemental ultraviolet-B and cadmium on growth, antioxidants and yield of Pisum sativum L. Ecotoxicol. Environ. Saf., 72: 610-618.

Bah A.M., Dai H., Zhao J., Sun H., Cao F., Zhang G. and Wu F. (2011). Effects of cadmium, chromium and lead on growth, metal uptake and antioxidative capacity in Typha angustifolia. Biol. Trace Elem. Res., 142: 77-92. 
Bartoli C.G., Yu J.P., Gomez F., Fernandez L., Mclntosh L. and Foyer C.H. (2006). Inter-relationships between light and respiration in the control of ascorbic acid synthesis and accumulation in Arabidopsis thaliana leaves. Journal of Experimental Botany, 57: 1621-1631.

Blaylock M. J. and Huang J.W. (2000). Phytoextraction of metals. Phytoremediation of toxic metals: using plants to clean up the environment. Eds., Raskin, I. and B.D. Ensley. John Wiley and Sons, Inc, Toronto, p. 303.

Cano-Asseleih L.M., Plumbly R.A. and Hylands P.J. (1989). Purificat ion and partial characterization of the hemagglutination from seeds of Jatropha curcas. J. Food Biochem., 13: 1-20.

Chen Y., Shen Z., Li X. (2004). The use of vetiver grass (Vetiveria zizanioides) in the phytoremediation of soils contaminated with heavy metals. Applied Geochemistry 19: 1553-1565.

Chen L., Han Y., Jiang H., Korpelainen H. and Li C. (2012). Nitrogen nutrient status induces sexual differences in responses to cadmium in Populus yunnanensis. J. Exp. Bot., 62: 5037-5050.

Divakara B.N., Upadhyaya H.D., Wani S.P., Laxmipathi C.L. (2010). Biology and genetics improvement of Jatropha curcas L. Appl. Ener., 87(3): 732742.

Dominguez M.T., Madrid F., Maranon T. and Murillo J.M. (2009). Cadmium availability in soil and retention in oak roots: potential for phytostabilization. Chemosphere, 76: 480-486.

Dubios M., Gilles K., Hamlton J., Rebers P. and Smith F. (1956).Colourimetric method for determination of sugars and related substances. Analytical Chemistry, 28(3): 350- 356.

Effendi Z., Ramli R. and Ghani J.A. (2010). A back propagation neural networks for grading Jatropha curcas fruits maturity. Am. J. Appl. Sci., 7: 390-394.

Fairless D. (2007). Biofuel: The little shrub that could - may be. Nature, 449, 652-655.

Foyer C.H., Descourvieres P. and Kunert K.J. (1994). Protection against oxygen radicals: an important defence mechanism studied in transgenic plants. Plant Cell Environ, 17: 507-523.

Ghavri S.V. and Singh R.P. (2010). Phytotranslocation of Fe by biodiesel plant Jatropha curcas L. grown on iron rich wasteland soil. Braz. J. Plant Physiol., 22: 235-243.

Ghavri S.V., Rawat S.K. and Singh R.P. (2010). Comparative study of growth and survival rate of Jatropha curcas clones (BTP-A, BTP-N and BTP-K) in the contaminated waste land soil from Sandila industrial area (SIA). Pollut. Res., 29: 519-522.

Giller K.E., Witter E. and McGrath S.P. (2009). Heavy metals and soil microbes.Soil Biol. Biochem., 41: 2031-2037.

Ginwal H.S., Rawat P.S. and Srivastava R.L. (2005). Seed Source Variation in Morphology, Germination and seedling growth of Jatropha curcas Linn. Central India Silvae Genet., 54: 76-80.

Gomez J.M., Hernandez J.A., Jimez A., Del rio L.A. and Sevilla F. (1999). Differential response of antioxidative enzymes of chloroplast and 
mitochondria to long term $\mathrm{NaCl}$ stress of pea plants. Free Radic Res., 31: 11-18.

Gunaseelan V.N. (2009). Biomass estimates, characteristics, biochemical methane potential, kinetics and energy flow f rom Jatropha curcas on dry lands. Biomass and Bioenergy, 33: 589-596.

Igbinosa O.O., Igbinosa E.O. and Aiyegoro O.A. (2009). Antimicrobial activity and phytochemical screening of stem bark extracts from Jatropha curcas (Linn). Afr. J. Pharm. Pharmacol., 3(2): 58-62.

Ishikawa T., Dowdle J. and Smirnoff N. (2006). Progress in manipulating ascorbic acid biosynthesis and accumulation in plants. Physiologia Plantarum, 126: 343-355.

Jackson N. L. (1958). Soil Chemical Analysis.Constable. Ltd. Co., London, 498 p.

Jamil S., Abhilash P.C., Singh N. and Sharma P.N. (2009). Jatropha curcas: a potential crop for phytoremediation of coal fly ash. J. Hazard. Mater., 172: 269-275.

Juwarkar A.A., Yadav S.K., Kumar P. and Singh S.K. (2008). Effect of biosludge and biofertilizer amendment on growth of Jatropha curcas in heavy metal contaminated soils. Environ. Monit. Assess., 145: 7-15.

Koller H.R. (1972). Leaf area, leaf weight relationship in the soybean canopy. Crop Sci., 12: 180-183.

Kumar G.P., Yadav S.K., Thawale P.R., Singh S.K. and Juwarkar A.A. (2008). Growth of Jatropha curcas on heavy metal contaminated soil amended with industrial wastes and Azotobacter. A greenhouse study. Bioresour. Technol., 99: 2078-2082.

Li X., Shen X., Li J., Eneji A.E., Li Z., Tian X. and Duan L. (2010). Coronatine alleviates water deficiency stress on winter wheat seedlings. J. Integr. Plant Biol., 52: 616-625.

Lim S.R. and Schoenung J.M. (2010). Human health and ecological toxici typotentials due to heavy metal content in waste electronic deviceswith flat panel displays. J. Haz. Mat., 177: 251-259.

Lindsay W.L. and Norvell W.A. (1978). Development of a DTPA soil test for zinc, iron, manganese and copper. Soil Sci. Soc. Am. J., 42: 421-428.

Lukacova Kulikova Z. and Lux A. (2010). Silicon influence on maize, Zea mays L., hybrids exposed to cadmium treatment. Bull. Environ. Contam. Toxicol., 85: 243-250.

Mahler R.J., Bingham F.T. and Chang A.C. (1981). Effect of heavy metal pollution on plants. Applied Science, 1:72-109.

Mangkoedihardjo S. and Sunahmadia (2008). Jatropha curcas L. for phytoremediation of lead and cadmium polluted soil. W. App. Sci. J., 4: 519-522.

Mohammad M., Maitra S., Ahmad N., Bustam A., Sen T.K. and Dutta B.K. (2010). Metal ion removal from aqueous solution using physic seed hull. J. Hazard. Mater., 179: 363-372.

Otieno D.O., Schmidt M.W., Adiku S. and Tenhunen J. (2005). Physiological and morphological responses to water stress in two Acacia species from contrasting habitats. Tree Physiol., 25: 361-371. 
Ovando-Medina I., Espinosa-García F.J., Núñez-Farfán J.S., SalvadorFigueroa M. (2011). State of the art of genetic diversity research in Jatropha curcas. Sci. Res. Essays, 6(8): 1709-1719.

Piotrowska A., Bajguz A., Godlewska-Zylkiewicz B. and Zambrzycka E. (2010). Changes in growth, biochemical components, and antioxidant activity in aquatic plant Wolffia arrhiza (Lemnaceae) exposed to cadmium and lead. Arch. Environ. Contam. Toxicol., 58: 594-604.

Piper O.S. (1947). Soil and plant Analysis. Adelaite University, Adelaide , Australia , 258-275.

Polle A., Chakrabarti K., Chakrabarti S., Seifert F., Schramel P. and Rennenberg H. (1992). Antioxidants and manganese deficiency in needles of Norway Spruce (Picea abies L.) trees. Plant Physiol., 99: 1084-1089.

Rafii M.Y., Shabanimofrad M., Wahab P.E.M. and Latif M.A. (2012). Analysis of the genetic diversity of physic nut, Jatropha curcas L. accessions using RAPD markers. Mol. Biol. Rep., DOI 10.1007/s11033-012-1478-2.

Rainbow P.S. (2007). Trace metal bioaccumulation. Models, metabolic availability and toxicity. Environ. Int., 33: 576-582.

Rao G.R., Korwar G.R., Shanker A.K. and Ramakrishna Y.S. (2008). Genetic associations, variability and diversity in seed characters, growth, reproductive phenology and yield in Jatropha curcas (L.) accessions. Trees Struct. Funct., 22: 697-709.

Shabanimofrad M., Yusop M.R., Saad M.S., Megat W.P.E., Biabanikhanehkahdani A., Latif M.A. (2011). Diversity of physic nut, Jatropha curcas in Malaysia-application of DIVA-GIS and cluster analysis. Aust. J. Crop Sci., 5(4): 361-368.

Sharma A., Sainger M., Dewedi S., Srivastva S., Tripathi R.D. and Singh R.P. (2010). Genotype variation in Brassica juncea L., Czern. cultivars in growth, ni $t$ rate assimi lat ion, ant ioxidant responses and phytoremediation potential during cadmium stress. J. Environ. Biol., 31:773-780.

Sharma B.D., Mukhopadhyay S.S. and Katyal J.C. (2006). Distribution of total and DTPA- extractable zinc, copper, manganese and iron in vertisols of India. Commun Soil Sci Plant Anal., 37: 653-672.

Simmons R.W., Pongsakul P. and Saiyasitpanich D. (2005). Elevated levels of cadmium and zinc in paddy soils and elevated levels of cadmium in rice grain downstream of zinc mineralized area in Thailand: implications for public health. Environmental Geochemistry and Health, 27:501-511.

Smith I.K., Vierheller T.L. and Thorne C.A. (1989). Properties and functions of glutathione reductase in plants. Physiol Plant, 77: 449- 456.

Snedecor G. and Cochran W. (1974). Statistical Methods. Sixth Edition. Iowa State University Press. Ames. lowa. USA.

Sudhakar T.J. and Nalini E. (2011). Molecular approaches to improvement of Jatropha curcas Linn. as a sustainable energy crop. Plant Cell Rep., 30: 1573-1591.

SWERI (2009). Annual Report. Soil, Water and Environmental Research Institute, different reports, Egypt. 
Tiryakioglu M., Eker S., Ozkutlu F., Husted S. and Cakmak I. (2006). Antioxidant defense system and cadmium uptake in barley genotypes differing in cadmium tolerance. J. Trace Elem. Med. Biol., 20: 181-189.

Unhalekhana U., and Kositanont C. (2008). Distribution of cadmium in soil around zinc mining area. Thai Journal of Toxicology, 23:170-174.

Wua G., Kanga H., Zhangc X., Shaob H., Chuc L. and Ruand C. (2010). A critical review on the bio-removal of hazardous heavy metals from contaminated soils: Issues, progress, eco-environmental concerns and opportunities. J. Haz. Mat., 174: 1-8.

Yadava U. (1986). A rapid and nondestructive method to determine chlorophyll in intact leaves. Hort. Sci., 21(6): 1449-1450.

\section{الملخص العربي \\ إستجابة نباتات الجاتروفا للرش بحمض الأسكوربيك لتخفيض الأثر الضار للتلوث بالكادميوم في ماء الري}

نادر أحمد الثنهورى' ، ماجدة عبد الحميد أحمد'

' فرع بحوث الحدائق النباتية بأنطونيادس - الإسكندرية- معهد بحوث البسانين - مركز البحوث الزراعية

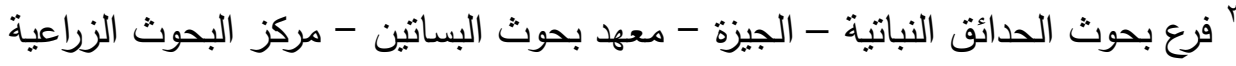

أجريت هذه الدراسة في فرع البحوث بأنطونياد، معهد بحوث البساتين، مركز البحوث الزراعية -

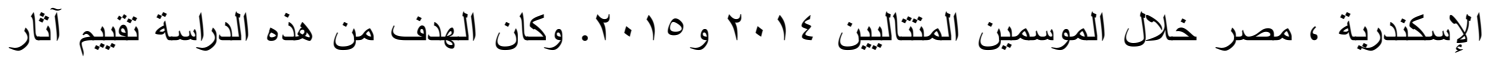

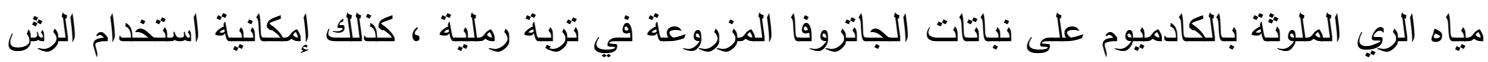
بحمض الاسكوربيك للتظلب على الآثار الضارة للكادميوم. زرعت شتلات الجاتروفا بشكل فردي في أوعية

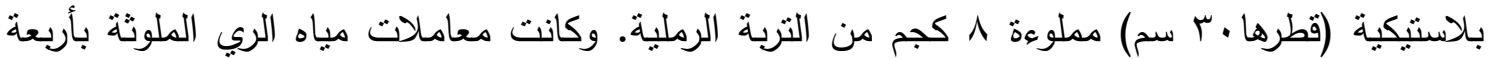

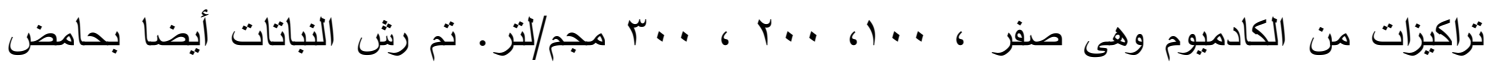

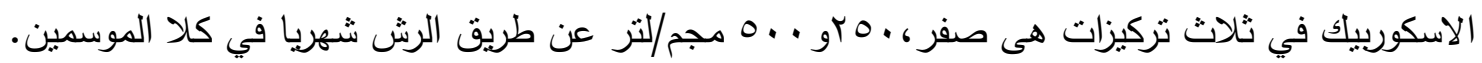

أظهرت النتائج أن هناك اختلاف كبير في التفاعل بين تركيزات الكادميوم ورش النباتات بحامض الاسكوربيك. وقد لوحظ انخفاض كبير في كافة معاملات الري بالماء الملوث بالكادميوم وكذلك لوجظ فئ

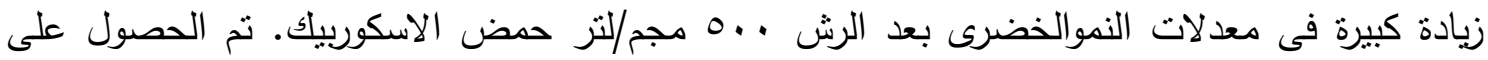

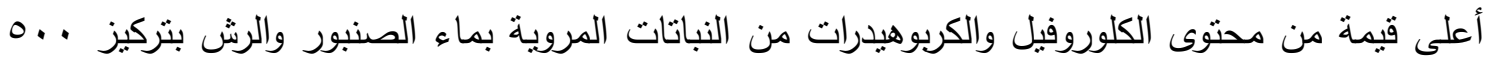
مجم/تنز حامض الاسكوربيك في حين أن أعلى كمية كبيرة من محتوى الكادميوم في الأوراق والساق

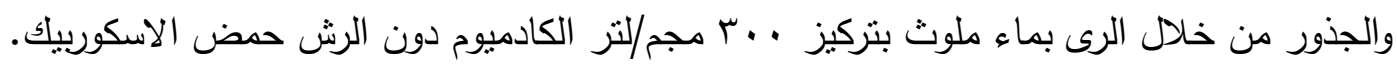


